\title{
Correlations of maternal and fetal endocrine events with uterine pressure changes around parturition in the ewe
}

\author{
N. C. Rawlings* and W. R. Ward \\ Department of Veterinary Clinical Studies, University of Liverpool, Leahurst, Neston, Wirral, \\ Merseyside, U.K.
}

\begin{abstract}
Summary. In 4 Clun Forest ewes maternal peripheral plasma concentrations of progesterone were still elevated at the onset of parturient uterine activity. Fetal and maternal plasma concentrations of oestrogen started to rise before parturition and concentrations in maternal plasma were positively correlated with parturient uterine activity $(P<0.05 ; r=+0.42)$. Fetal plasma concentrations of corticosteroids were positively correlated with fetal plasma concentrations of oestrogen $(P<0.01 ; r=+0.65)$, but negatively correlated with maternal peripheral plasma progesterone concentrations $(P<0.05 ; r=-0.50)$. Before parturition plasma concentrations of PGF rose but stayed high only in maternal peripheral plasma. Maternal peripheral plasma concentrations of PGF were positively correlated with uterine activity $(P<0.05 ; r=+0.79)$ and plasma concentrations of oestrogen $(P<0.05 ; r=+0.79)$, but negatively correlated with plasma concentrations of progesterone $(P<0.01 ; r=-0.54)$.
\end{abstract}

\section{Introduction}

The hormonal changes in ewes during late pregnancy and parturition have been studied by many workers. The temporal patterns of peripheral plasma concentrations of progesterone around parturition have been described (Bassett, Oxborrow, Smith \& Thorburn, 1969; Fylling, 1970; Stabenfeldt, Drost \& Franti, 1972), and Challis (1971) estimated total unconjugated oestrogens in maternal peripheral plasma during late pregnancy. After the discovery of the importance of the fetal pituitaryadrenal axis for parturition in the ewe (Liggins, Kennedy \& Holm, 1968), the changes in concentrations of glucocorticoids in the ovine fetal circulation have been investigated (Comline, Nathanielsz, Paisey \& Silver, 1970; Bassett \& Thorburn, 1973; Drost, Kumagae \& Guzman, 1973). Concentrations of prostaglandin (PG) F and F-2 $\alpha$ in the uterine vein blood before parturition have been measured by Thorburn, Nicol, Bassett, Shutt \& Cox (1972b) and by Challis, Harrison, Heap, Horton \& Poyser (1972). Challis, Dilley, Robinson \& Thorburn (1976) have investigated the changes in concentrations of PGF and PGE in fetal plasma during late pregnancy. Ward (1968) observed that parturition in the ewe, as indicated by uterine pressure changes, lasted for only 12-24 h.

The present study correlates the temporal patterns of maternal jugular plasma concentrations of oestrogen, progesterone, glucocorticoids and PGF, and fetal carotid plasma oestrogens, glucocorticoids and PGF with the onset and development of parturient uterine activity in sheep. An attempt has also been made to identify the quantitatively important oestrogens and glucocorticoids.

\section{Materials and Methods}

\section{Surgical procedures}

Laparotomy was performed on 4 multiparous Clun Forest ewes on Days 135 or 136 of gestation to introduce a balloon-ended pressure-recording cannula (Portex-800/100/300) into the uterus and a polyvinyl chloride cannula (length $145 \mathrm{~cm}$, Portex no. 800/000/150-195) into a fetal carotid artery.

* Present address : Department of Veterinary Physiological Sciences, College of Veterinary Science, University of Saskatchewan, Saskatoon, Saskatchewan, Canada S7N 0W0. 
Surgery was performed under anaesthesia induced and maintained with methohexitone sodium (Brietal: Eli Lilly; $6 \mathrm{mg} / \mathrm{kg}$ i.v. for induction, intermittent injection of a $1 \%$ solution for maintenance). The recording cannula was positioned outside the fetal membranes in the same horn as the cannulated fetus; the carotid artery was cannulated conventionally (peripheral occlusion). Two ewes (Nos 5 and 18) carried only one fetus each; Ewes 12 and 70 carried twins, of which only one was cannulated. Patency of the fetal cannula was maintained by constant infusion of sterile heparinized saline ( $2 \mathrm{ml} / \mathrm{h})$.

\section{Sampling procedures}

The ewes were bled by jugular venepuncture on alternate days for 10 days before surgery. Subsequently, blood samples were withdrawn simultaneously from the ewe (15 ml) and her fetus ( $3 \mathrm{ml})$, every evening (16:00-17:00 h) until Day 141 of gestation and then every $6 \mathrm{~h}$ until parturition. Additional samples were obtained in the periparturient period. The more frequent samples were taken by way of an indwelling polythene jugular cannula, inserted by using local anaesthesia on Day 141 . Blood samples were centrifuged immediately and the plasma was stored at $-20^{\circ} \mathrm{C}$ until assayed.

Uterine pressure recordings were made at the same times as for the bleeding schedule by coupling the air-filled cannula to a pressure-sensitive transducer and two-channel recorder (Devices). Uterine activity is presented as Montevideo units (MU: Alvarez \& Caldeyro-Barcia, 1950), calculated as a function of the amplitude $(\mathrm{mmHg})$ and the number of contractions in $10 \mathrm{~min}$.

\section{Analytical procedures}

Progesterone, total unconjugated oestrogens, glucocorticoids and PGF concentrations were measured in the plasma samples by liquid-phase radioassays. Some samples were also used for measurement of total unconjugated oestradiol, oestradiol-17 $\alpha$, oestrone, cortisol, corticosterone, 11-deoxycortisol and 11-deoxycorticosterone concentrations by radioimmunoassays after column chromatography. All estimations were performed in duplicate and corrected for procedural losses. The sensitivity, interassay coefficients of variation and the accuracy of the assays are given in Table 1. Sensitivity was defined as the smallest quantity of unlabelled purified hormone capable of displacing significant amounts of labelled hormone from the binding protein $(P<0.01)$, or, when a significant water blank was found, the mean blank value plus twice the standard deviation of the blank was used (see Table 1). Coefficients of variation were obtained by the repeated analysis of pooled plasma samples containing known concentrations of purified hormone. Accuracy was determined by repeated analysis of plasma to which known amounts of purified hormone were added; values obtained were corrected for the endogenous hormone concentration.

Progesterone and total unconjugated oestrogens were measured by the assays described by Rawlings \& Ward (1976).

Glucocorticoids were estimated by a competitive binding assay based on that of Murphy (1967). Progesterone was removed from the plasma samples by partition with petroleum ether. Plasma proteins were precipitated with ethanol and the residues of the ethanolic extracts were assayed, without further purification, by using dog corticoid-binding globulin and charcoal as the adsorbant. No significant assay blank values were encountered.

Prostaglandin $F$ was measured after extraction from acidified plasma with ethyl acetate. The antiserum, raised against PGF-2 $\alpha$, had a $33 \%$ cross-reaction with PGF-1 $\alpha$, but was otherwise specific. Values are therefore expressed as concentrations of $\mathrm{PGF} / \mathrm{ml}$ plasma. A significant assay blank value of $3 \pm 2 \cdot 17 \mathrm{pg}$ was found (s.e.m.; $n=10$ ).

Oestrogens were estimated individually after separation on columns of Sephadex LH-20 (0.6 $\times$ $9.5 \mathrm{~cm})$, with the solvent system benzene-methanol $(96: 5 \mathrm{v} / \mathrm{v})$. After chromatography oestrone was measured by using an antiserum to oestradiol-17ß that cross-reacted with oestrone. $\left[2,4,6,7(\mathrm{n})-{ }^{3} \mathrm{H}\right]-$ Oestrone was used as the labelled competitor with oestrone standards. The oestradiol fraction was split; half was analysed with a specific oestradiol-17 $\alpha$ antiserum (Dobson \& Dean, 1974), and the other half with an oestradiol-17 $\beta$ antiserum that cross-reacted with oestradiol-17 $\alpha$ (total oestradiol). The mean ( \pm s.e.m.) blank value for the column effluent estimated in any assay system was $2 \pm 1 \mathrm{pg}$ $(n=51)$. 
Table 1. Quality control data for the radioimmunoassays used in the present experiments (number of observations in parentheses)

\begin{tabular}{|c|c|c|c|c|}
\hline \multirow[b]{2}{*}{ Hormone } & \multirow[b]{2}{*}{$\begin{array}{l}\text { Sensitivity } \dagger \\
\quad(\mathrm{pg})\end{array}$} & \multirow{2}{*}{$\begin{array}{c}\text { Interassay coefficient } \\
\text { of variation* } \\
(\%)\end{array}$} & \multicolumn{2}{|c|}{ Accuracy } \\
\hline & & & $\begin{array}{c}\text { Amount } \\
\text { added }\end{array}$ & $\begin{array}{l}\text { Amount } \\
\text { obtained }\end{array}$ \\
\hline Glucocorticoids & $100(30)$ & $14 \cdot 70 \pm 0.86(67)$ & $\begin{array}{l}0.4 \mathrm{ng}(17) \\
0.7 \mathrm{ng}(20) \\
1.8 \mathrm{ng}(25) \\
3.5 \mathrm{ng}(3) \\
7.0 \mathrm{ng}(3)\end{array}$ & $\begin{array}{l}0.4 \pm 0.0 \mathrm{ng} \\
0.8 \pm 0.0 \mathrm{ng} \\
1.8 \pm 0.1 \mathrm{ng} \\
3.5 \pm 0.1 \mathrm{ng} \\
7.5 \pm 0.1 \mathrm{ng}\end{array}$ \\
\hline Prostaglandin F & $11(10) \ddagger$ & $15.88 \pm 7.54(9)$ & $\begin{array}{r}20 \mathrm{pg}(3) \\
50 \mathrm{pg}(3) \\
100 \mathrm{pg}(3)\end{array}$ & $\begin{array}{l}16 \pm 4 \mathrm{pg} \\
49 \pm 1 \mathrm{pg} \\
78 \pm 2 \mathrm{pg}\end{array}$ \\
\hline Progesterone & $29(23) \ddagger$ & $17.22 \pm 2.01(37)$ & $\begin{array}{l}50 \mathrm{pg}(7) \\
100 \mathrm{pg}(11) \\
250 \mathrm{pg}(9) \\
500 \mathrm{pg}(10)\end{array}$ & $\begin{array}{r}68 \pm 11 \mathrm{pg} \\
119 \pm 11 \mathrm{pg} \\
244 \pm 9 \mathrm{pg} \\
451 \pm 17 \mathrm{pg}\end{array}$ \\
\hline $\begin{array}{l}\text { Total unconjugated } \\
\text { oestrogens }\end{array}$ & $5(30)$ & $16.08 \pm 0.86(92)$ & $\begin{array}{c}20 \mathrm{pg}(27) \\
50 \mathrm{pg}(50) \\
70 \mathrm{pg} \mathrm{(6)} \\
100 \mathrm{pg}(9)\end{array}$ & $\begin{array}{l}22 \pm 1 \mathrm{pg} \\
49 \pm 1 \mathrm{pg} \\
72 \pm 6 \mathrm{pg} \\
89 \pm 4 \mathrm{pg}\end{array}$ \\
\hline Oestrone & $8(50) \ddagger$ & $6.00 \pm 0.74(8)$ & $50 \mathrm{pg}(8)$ & $48 \pm 3 \mathrm{pg}$ \\
\hline Oestradiol (total) & $8(50) \ddagger$ & $12.01 \pm 1.24(8)$ & $100 \mathrm{pg}(8)$ & $107 \pm 6 \mathrm{pg}$ \\
\hline Oestradiol-17 $\alpha$ & $8(50) \ddagger$ & $13.56 \pm 1.56(7)$ & $50 \mathrm{pg}(7)$ & $51 \pm 3 \mathrm{pg}$ \\
\hline Cortisol & 100 & $12.01 \pm 5.46(6)$ & $1 \cdot 4 \mathrm{ng}(5)$ & $1.3 \pm 0.2 \mathrm{ng}$ \\
\hline 11-Deoxycortisol & 100 & & $0.9 \mathrm{ng}(5)$ & $0.7 \pm 0.1 \mathrm{ng}$ \\
\hline Corticosterone & 100 & & $2 \cdot 6 \mathrm{ng}(5)$ & $1.8 \pm 0.2 \mathrm{ng}$ \\
\hline 11-Deoxycorticosterone & 200 & & $1 \cdot 3 \mathrm{ng}(1)$ & $1 \cdot 2 \mathrm{ng}$ \\
\hline
\end{tabular}

\footnotetext{
* Mean \pm s.e.m.

$\dagger$ Per assay tube.

$\ddagger$ Assay water blank plus twice the standard deviation of the water blank.
}

Cortisol, corticosterone, 11-deoxycortisol and 11-deoxycorticosterone were separated on columns of Sephadex LH-20 $(1 \times 26 \mathrm{~cm})$ by using methylene dichloride-methanol $(98: 2 \mathrm{v} / \mathrm{v})$ as the eluant. Blank values for column eluant fractions were consistently zero. The detection limit of all 4 individual corticoids measured was $3 \mathrm{ng} / \mathrm{ml}$ plasma.

\section{Statistical analysis}

The data were assessed by analysis of variance (one-way classification, any number of groups with unequal replication), and, when appropriate, by Kramer's modification of Duncan's New Multiple Range Test. Simple correlation and regression analyses were employed (Steel \& Torrie, 1960). For the statistical analyses only, the results obtained at the last sampling period before parturition were regarded as being at $6 \mathrm{~h}$ before birth and those obtained within $1 \mathrm{~h}$ of birth were regarded as being at parturition. 


\section{Results}

All ewes underwent normal parturition and gave birth to healthy active lambs after gestation lengths of 144, 145, 143 and 145 days for Ewes 5, 70, 18 and 12 respectively (mean, 144 days; flock average, 145 days). The cannulated twin was expelled second from Ewes 12 and 70.

The temporal patterns of the hormone concentrations in systemic plasma and the uterine activity for the ewes and their fetuses are shown in Text-fig. 1. The parturient uterine activity lasted for 9-12 $\mathrm{h}$.

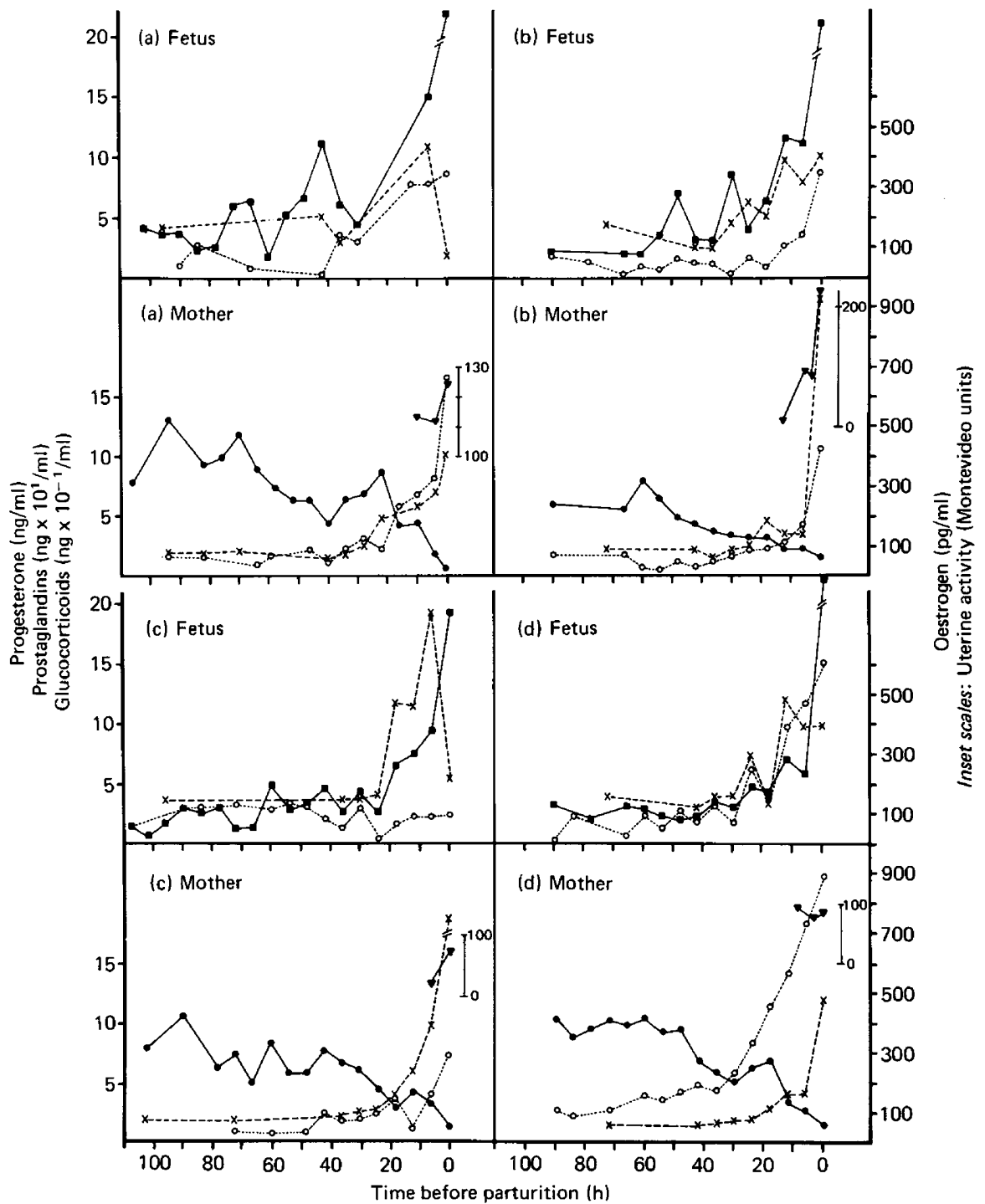

Text-fig. 1. Concentrations of glucocorticoids $(\square-\square)$, total unconjugated oestrogens $(0---O)$ and prostaglandin $F(x---x)$ in fetal and maternal plasma, and of progesterone $(-0)$ in maternal plasma, and uterine activity ( $\nabla-\nabla)$ during the last 4 days of gestation in (a) Ewe 5 (single fetus), (b) Ewe 18 (single fetus), (c) Ewe 12 (twins, cannulated twin born second) and (d) Ewe 10 (twins, cannulated twin born second). Parturition is at $0 \mathrm{~h}$.

Progesterone. Average maternal jugular plasma concentrations of progesterone fell significantly during the last $50 \mathrm{~h}$ of gestation $(P<0.005)$; the mean concentration was $3.36 \pm 0.42 \mathrm{ng} / \mathrm{ml}$ (s.e.m.; 
$n=4$ ) at the onset of parturient uterine activity and concentrations declined more during parturition. Progesterone concentrations were negatively correlated with uterine activity (Table 2).

Table 2. Some correlations between fetal and maternal endocrine changes and between these and uterine activity at parturition in the ewe (numbers in parentheses are the numbers of pairs of observations involved in each correlation)

\begin{tabular}{lllll}
\hline & $\begin{array}{c}\text { Uterine } \\
\text { activity }\end{array}$ & $\begin{array}{c}\text { Fetal } \\
\text { oestrogens }\end{array}$ & $\begin{array}{c}\text { Fetal } \\
\text { corticoids }\end{array}$ & $\begin{array}{c}\text { Maternal } \\
\text { †prostaglandin F }\end{array}$ \\
\hline Maternal oestrogens & $+0 \cdot 42^{*}(13)$ & $+0 \cdot 89^{* *}(59)$ & $+0 \cdot 65^{* *}(60)$ & $+0 \cdot 79^{*}(42)$ \\
Maternal progesterone & $-0.39^{*}(13)$ & & $-0.50^{*}(72)$ & $-0.54^{* *}(40)$ \\
Maternal prostaglandin $\mathrm{F}$ & $+0 \cdot 79^{*}(10)$ & & & \\
\hline
\end{tabular}

${ }^{*} P<0.05 ;{ }^{* *} P<0.01$

Oestrogens. Mean concentrations of oestrogen rose in parallel in fetal and maternal plasma during the imımediate pre-partum period $(P<0.01$ and $P<0.005$ respectively), reaching values of $279 \pm 101$ $\mathrm{pg} / \mathrm{ml}(n=4)$ in maternal plasma at the onset of uterine activity; this increase continued rapidly during parturition. In the fetus of Ewe 12 there was no rise in plasma oestrogen concentrations. The relative concentrations of total oestradiol, oestrone and oestradiol-17 $\alpha$ in maternal and fetal plasma were not significantly different at 5 days and 1 day before and at parturition (Table 3). Maternal plasma concentrations of oestrogens and uterine activity were correlated.

Table 3. Oestradiol (total), oestrone and oestradiol- $17 \alpha$ concentrations $(\mathrm{pg} / \mathrm{ml})$ in maternal peripheral and fetal carotid plasma, at 5 days and 1 day before and on the day of parturition in 4 ewes

\begin{tabular}{|c|c|c|c|c|c|c|c|}
\hline \multirow{2}{*}{$\begin{array}{c}\text { Time before } \\
\text { parturition } \\
\text { (days) }\end{array}$} & \multirow[b]{2}{*}{ Ewe } & \multicolumn{3}{|c|}{ Maternal blood } & \multicolumn{3}{|c|}{ Fetal blood } \\
\hline & & Oestradiol & Oestrone & Oestradiol-17 $\alpha$ & Oestradiol & Oestrone & Oestradiol-17 $\alpha$ \\
\hline \multirow[t]{4}{*}{5} & 18 & 12 & 14 & 12 & 7 & 100 & 42 \\
\hline & 70 & 35 & 43 & 35 & 17 & 50 & 52 \\
\hline & 5 & 33 & 18 & 17 & 14 & 24 & 10 \\
\hline & 12 & 19 & 20 & 8 & 35 & 23 & 49 \\
\hline \multirow[t]{4}{*}{1} & 18 & 26 & 22 & 25 & 24 & 52 & 21 \\
\hline & 70 & 80 & 139 & 56 & 35 & 93 & 56 \\
\hline & 5 & 44 & 49 & 14 & 23 & 29 & 5 \\
\hline & 12 & 30 & 34 & 17 & 21 & 43 & 35 \\
\hline \multirow[t]{4}{*}{0} & 18 & 234 & 206 & 152 & 208 & 235 & 181 \\
\hline & 70 & 504 & 612 & 313 & 382 & 372 & 313 \\
\hline & 5 & 368 & 235 & 84 & 129 & 248 & 54 \\
\hline & 12 & 78 & 97 & 57 & - & 26 & 19 \\
\hline
\end{tabular}

Glucocorticoids. Fetal plasma concentrations rose from $20.99 \pm 4.97 \mathrm{ng} / \mathrm{ml}(n=3) 8$ days before parturition to $110 \cdot 31 \pm 17 \cdot 60 \mathrm{ng} / \mathrm{ml}(n=3)$ at the onset of uterine activity $(P<0.005)$ and continued to rise throughout parturition. During the period of study, plasma concentrations of glucocorticoids were higher $(47 \cdot 3 \pm 9 \cdot 4 \mathrm{ng} / \mathrm{ml} ; n=76)$ in the fetus than in maternal jugular plasma $(7 \cdot 1 \pm 1 \cdot 4 \mathrm{ng} / \mathrm{ml}$; $n=72 ; P<0.005)$; the latter did not change significantly during the study. Fetal plasma concentrations were positively correlated with maternal plasma concentrations of oestrogen and negatively correlated with maternal plasma concentrations of progesterone.

$P G F$. The concentrations of PGF in maternal jugular and fetal carotid plasma rose during the $30 \mathrm{~h}$ before parturition $(P<0.005)$, reaching concentrations of $0.59 \pm 0.15 \mathrm{ng} / \mathrm{ml}(n=4)$ and $1.36 \pm 0.21$ $\mathrm{ng} / \mathrm{ml}(n=3)$ respectively, at the onset of parturient uterine activity. During parturition the rise 
continued in maternal blood, but concentrations in fetal blood fell after the onset of parturition in 3 animals and rose slightly in the other (Ewe 18). Maternal plasma concentrations of PGF were positively correlated with maternal plasma concentrations of oestrogen and uterine activity but negatively correlated with maternal plasma concentrations of progesterone.

Corticoids. In fetal and maternal plasma obtained at 7, 3 and 1 day(s) before and at parturition, only cortisol was detected of the 4 adrenal corticoids investigated. Although the cortisol values were lower than the estimates of total glucocorticoids, the two values fluctuated in parallel $(P<0.01$, $r=+0.95)$.

\section{Discussion}

The concentrations and temporal pattern of maternal progesterone seen in the present study closely resemble the results of other workers (Bassett et al., 1969; Fylling, 1970; Stabenfeldt et al., 1972). The previous and present results indicate that, in the ewe, parturition is initiated while there are still high circulating concentrations of progesterone. However, progesterone withdrawal appears to be essential for the development of maximal uterine activity and for normal cervical dilatation (Bengtsson \& Schofield, 1963; Hindson, Schofield \& Turner, 1968; Hindson, Schofield \& Ward, 1969; Liggins, Grieves, Kendall \& Knox, 1972).

The present observations of an increase in maternal peripheral plasma concentrations of total unconjugated oestrogens during late gestation are similar to those of Challis (1971). Oestrogen concentrations clearly rose before parturient uterine activity began, but the close and positive correlation between the two suggests a cause and effect relationship. Parturition can be induced in the ewe with oestrogenic compounds (Hindson, Schofield \& Turner, 1967). Although circulating concentrations of oestrogen did not rise in the cannulated fetus of Ewe 12, changes in the other hormones resembled those in the other 3 ewes. The cannulated fetus of Ewe 12 was one of twins and was born after the other; it is possible that the first lamb may have played a more definitive role in initiating parturition (Liggins et al., 1968).

Bedford, Challis, Harrison \& Heap (1972) suggested that oestrone was the predominant oestrogen found in maternal plasma of the periparturient ewe. The present study supports this, but, although less oestradiol-17 $\alpha$ appeared to be present, the difference was not significant. Bedford et al. (1972) suspected that their total oestrogen estimations underestimated total oestrogen concentration because of interactions in the assay system and similar competition may explain the similar concentrations of total oestradiol and oestradiol-17 $\alpha$ in the present study. However, Bedford et al. (1972) indicated that the concentrations of oestrone were approximately 2- to 9-fold higher than oestradiol$17 \beta$, and therefore oestrone is probably the predominant circulating oestrogen in the parturient ewe, followed by oestradiol-17 $\alpha$, with oestradiol-17 $\beta$ being of minor importance.

Fetal carotid plasma concentrations of glucocorticoids rose over the last 8 days of gestation, in a pattern similar to that seen by previous workers (Comline et al., 1970; Bassett \& Thorburn, 1973; Drost et al., 1973). The fetal pituitary and adrenal are essential for the occurrence of parturitionat the normal time (Liggins et al., 1968) and fetal glucocorticoids have been implicated as the adrenal mediator of this effect (Liggins, 1969). The temporal pattern of fetal circulating concentrations of glucocorticoids observed in the present study would support the importance of cortisol in the initiation of normal parturition.

The increase in circulating PG concentrations in the late pregnant ewe is due to increased uterine production (Thorburn et al., 1972b). The uterine venous blood concentrations in late pregnancy (Thorburn et al., 1972b) are about 10-20 times higher than those observed in fetal blood in the present study. Challis et al. (1976) investigated PG concentrations in ovine fetal blood samples taken every other day during late pregnancy: PGF concentrations were lower than those found in the present ewes and no elevations around parturition were noted, although concentrations of PGE were higher and appeared to rise just before parturition. Prostaglandin $\mathrm{F}$ is probably produced by the endometrium (Liggins et al., 1972). The reason why fetal PGF levels are so low is not clear; it could be caused by 
selective transport by the placenta, or metabolism within the fetal blood compartment. The enzyme systems responsible for PG metabolism appear to be present in fetal lungs (Sun \& Armour, 1974; Olley, Coceani \& Kent, 1974), but only 5-10\% of the output of the fetal heart is supplied to the lungs. The decrease in fetal plasma concentration of PGF at the onset of parturition in the present study might have been due to circulatory disruption caused by uterine activity or perhaps to an increased perfusion of the fetal lungs. Prostaglandins have been shown to cause constriction of the umbilical vessels in the ewe (Dyer, 1970).

The temporal pattern of PGF concentrations seen in the maternal jugular venous blood in the present work resembles that in the uterine vein (Thorburn et al., 1972b) and utero-ovarian vein (Flint, Anderson, Patten \& Turnbull, 1974), although the actual concentrations were approximately 10-fold lower because of the metabolism of prostaglandins which occurs in the lungs (Piper, Vane \& Wyllie, 1970). Similarly, in non-pregnant ewes, the temporal pattern of PGF concentrations in uteroovarian vein blood resembles that in jugular blood, but the latter values are approximately 10-fold lower (Thorburn, Cox, Currie, Restall \& Schneider, 1972a; Caldwell, Tillson, Brock \& Speroff, 1972).

A possible role of oestrogens in the stimulation of PGF- $2 \alpha$ output at parturition in the ewe is suggested by the present results and previous work (Challis et al., 1972), but the opposite effect of PGF- $2 \alpha$ on oestrogen production has also been indicated (Liggins et al., 1972). Liggins et al. (1972) also failed to demonstrate a direct oxytocic effect of PGF- $2 \alpha$ on the gravid ovine uterus betore parturition. The role of prostaglandins in ovine parturition therefore requires further study.

The oestrogen antiserum (No. SLC-10C) was a gift of Dr B. V. Caldwell (Yale University, U.S.A.), the progesterone antiserum (No. 465/4-5) a gift of Dr B. J. A. Furr (N.I.R.D., Reading) and the PGF antiserum (No. XX) was raised by Dr C. S. Sharma in this laboratory. We thank Mr J. E. Cox for the anaesthesia and Mrs A. Gillette and Mrs S. Midmer for technical assistance. This work was supported in part by a grant from the Medical Research Council.

\section{References}

Alvarez, H. \& Caldeyro-Barcia, R. (1950) Contractility of the human uterus recorded by new methods. Surgery, Gynec. Obstet. 91, 1-13.

BassetT, J.M. \& Thorburn, G.D. (1973) Circulating levels of progesterone and corticosteroids in the pregnant ewe and its foetus. In The Endocrinology of Pregnancy and Parturition-Experimental Studies in the Sheep, pp. 126-140. Ed. C. G. Pierrepoint. Alpha Omega Alpha, Cardiff.

BassetT, J.M., Oxborrow, T.J., SMith, I.D. \& ThORBURN, G.D. (1969) The concentration of progesterone in the peripheral plasma of the pregnant ewe. $J$. Endocr. 45, 449-457.

Bedford, C.A., Challis, J.R.G., Harrison, F.A. \& HeAP, R.B. (1972) The role of oestrogens and progesterone in the onset of parturition in various species. J. Reprod. Fert., Suppl. 16, 1-23.

Bengtsson, L.P. \& Schofield, B.M. (1963) Progesterone and the accomplishment of parturtion in the sheep. J. Reprod. Fert. 5, 423-431.

Caldwell, B.V., Tillson, S.A., Brock, A. \& SperofF, L. (1972) The effects of exogenous progesterone and estradiol on prostaglandin $F$ levels in ovariectomised ewes. Prostaglandins 1, 217-227.

Challis, J.R.G. (1971) Sharp increase in free circulating oestrogen immediately before parturition in sheep. Nature, Lond. 229, 208.

Challis, J.R.G., Harrison, F.A., Heap, R.B., Horton, E.W. \& POYSER, N.L. (1972) A possible role of oestrogens in the stimulation of prostaglandin $\mathbf{F}_{2 a}$ output at the time of parturition in a sheep. J. Reprod. Fert. 30, 485-488.

Challis, J.R.G., Dilley, S.R., Rominson, J.W. \& Thorburn, G.D. (1976) Prostaglandins in the circulation of the fetal lamb. Prostaglandins 11, 1041-1052.

Comline, R.S., Nathanielsz, P.W., Paisey, R.B. \& Silver, M. (1970) Cortisol turnover in the sheep foetus immediately prior to parturition. J. Physiol., Lond. 210, 141-142.

Dosson, H. \& DEAN, P.D.G. (1974) The use of radioimmunoassay to determine the relationship between oestrone, $17 \beta$ - and $17 \alpha$-oestradiol in bovine plasma during the oest rous cycle and last stages of pregnancy. $J$. Endocr. 61, 479-486.

Drost, M., Kumagae, L.F. \& Guzman, M. (1973) Sequential foetal-maternal plasma cortisol levels in sheep. J. Endocr. 56, 483-492.

Dyer, D.C. (1970) Comparison of the constricting actions produced by serotonin and prostaglandins on isolated sheep umbilical arteries and veins. Gynec. Invest. 1, $204-209$.

Flint, A.P.F., Anderson, A.B.M., Patten, P.T. \& Turnbull, A.C. (1974) Control of utero-ovarian venous prostaglandin $F$ during labour in the sheep: acute effects of vaginal and cervical stimulation. $J$. Endocr. 63, 67-87.

FyLLING, P. (1970) The effect of pregnancy, ovariectomy Downloaded from Bioscientifica.com at 04/26/2023 01:34:09PM via free access 
and parturition on plasma progesterone levels in sheep. Acta endocr., Copenh. 65, 273-283.

Hindson, J.C., SChofield, B.M. \& TuRner, C.B. (1967) The effect of a single dose of stilboestrol on cervical dilation in pregnant sheep. Res. vet. Sci. 8, 353-360.

Hindson, J.B., Schofield, B.M. \& Turner, C.B. (1968) Some factors affecting dilation of the ovine cervix. Res. vet. Sci. 9, 474-480.

Hindson, J.B., Schofifld, B.M. \& WARd, W.R. (1969) The effect of progesterone on recorded parturition and on oxytocin sensitivity in the sheep. $J$. Endocr. 43, 207-215.

Liggins, G.C. (1969) Premature delivery of fetal lambs infused with glucocorticoids. J. Endocr. 45, 515-523.

Ligains, G.C., Kennedy, P.C. \& Holm, L.W. (1968) Failure of initiation of parturition after electrocoagulation of the pituitary of the fetal lamb. Am.J. Obstet. Gynec. 98, 1080-1086.

Liggins, G.C., Grieves, S.A., Kendall, J.Z. \& K.rox, B.S. (1972) The physiological roles of progesterone, oestradiol-17 $\beta$ and prostaglandin $F_{2 \alpha}$ in the control of ovine parturition. J. Reprod. Fert., Suppl. 16, 85103.

MurPhY, B.E.P. (1967) Some studies of the protein binding of steroids and their application to the routine micro and ultra-micro measurement of various steroids in body fluids by competitive protein binding radioassay. J. clin. Endocr. Metab. 27, 973992.

Olley, P.M., Coceani, F. \& Kent, G. (1974) Inactivation of prostaglandin $E_{1}$ by lungs of the fetal lamb. Experientia 30, 58-59.
Piper, P.J., VANe, J.R. \& Wyllie, J.H. (1970) Inactivation of prostaglandins by the lungs. Nature, Lond. $225,600-604$.

Rawlings, N.C. \& WARD, W.R. (1976) Changes in steroid hormones in plasma and myometrium and uterine activity in ewes during late pregnancy and parturition. J. Reprod. Fert. 48, 355-360.

Stabfnfeldt, G.H., Drost, M. \& FRANTi, C.E. (1972) Peripheral progesterone levels in the ewe during pregnancy and parturition. Endocrinology 90, 144150.

Steel, R.G.D. \& Torrie, J.H. (1960) Principles and Procedures of Statistics. McGraw-Hill, New York.

Sun, F.F. \& ARmour, S.B. (1974) Prostaglandin 15hydroxy dehydrogenase and $\Delta^{13}$ reductase levels in the lungs of maternal, fetal and neonatal rabbits. Prostaglandins 7, 327-338.

Thorburn, G.D., Cox, R.I., Currie, W.B., Restall, B.J. \& SCHNeideR, W. (1972a) Prostaglandin F concentration in the utero-ovarian venous plasma of the ewe during the oestrous cycle. $J$. Endocr. 53, 325326.

Thorburn, G.D., Nicol, D.H., Bassett, J.M., Shutt, D.A. \& Cox, R.I. (1972b) Parturition in the goat and sheep: changes in corticosteroids, progesterone, oestrogens and prostaglandins F. J. Reprod. Fert., Suppl. 16, 61-84.

WARD, W.R. (1968) Structure and function of the ovine cervix uteri. Ph.D. thesis, University of Liverpool.

Received 25 March 1977 